Article

\title{
Genotype and Planting Date Influence on Establishment and Growth of Bassia prostrata (L) A.J. Scott in a Semiarid Subtropical Dry Winter Region
}

\author{
Leonard Lauriault ${ }^{1, *}$ and Blair L. Waldron ${ }^{2}$ D \\ 1 Rex E. Kirksey Agricultural Science Center at Tucumcari, New Mexico State University, Tucumcari, \\ NM 88401, USA \\ 2 USDA-ARS Forage and Range Research Lab, Logan, UT 84322, USA; blair.waldron@usda.gov \\ * Correspondence: lmlaur@nmsu.edu; Tel.: +1-5750461-1620
}

Received: 21 December 2019; Accepted: 5 February 2020; Published: 8 February 2020

check for updates

\begin{abstract}
Alfalfa (Medicago sativa L.) growers in semiarid subtropical regions seek forage crops having a lower irrigation requirement. Perennial forage kochia (Bassia prostrata (L) A.J. Scott (syn. Kochia prostrata)) can potentially fill this need. The New Mexico State University's Agricultural Science Center at Tucumcari evaluated four genotypes of B. prostrata (subspecies virescens "Immigrant" and "Pustinny-select" and subsp. grisea "Snowstorm" and "KZ-6X") that were direct-seeded in March and May of 2014 under irrigation in semiarid continental precipitation conditions, in three randomized complete blocks. Canopy cover was rated in 2016 and 2018 and biomass production was measured in 2018. Snowstorm did not establish on either date. Canopy cover remained unchanged across years. Immigrant established the greatest canopy cover for the March seeding and Pustinny-select had greater canopy cover for the May seeding. The May seeding tended $(p<0.10)$ to have greater biomass production than the March seeding $\left(12,357\right.$ and $8909 \mathrm{~kg} \mathrm{ha}^{-1}$, respectively, SEM $=2454$ ). Irrigation or adequate precipitation to maintain soil moisture and weed control are critical to B. prostrata establishment by direct seeding, especially in dry winter regions. Further research is necessary to determine the potential of this species as an alternative to alfalfa in semiarid, subtropical, and continental precipitation regions.
\end{abstract}

Keywords: Bassia prostrata; perennial forage kochia; evergreen semishrub; canopy cover; establishment

\section{Introduction}

While the demand for available forage for livestock production is increasing in semiarid regions [1], such as the Southern High Plains of the USA, declining water tables and intermittent drought are prompting alfalfa (Medicago sativa) growers, in those regions, to seek alternative forage crops with a lower irrigation requirement for use as hay or pasture. Perennial forage kochia (Bassia prostrata (L) A.J. Scott (syn. Kochia prostrata)) is known as "the alfalfa of the desert" in its area of origin because of its forage value for ruminants [2,3]. Bassia prostrata is a long-lived semishrub (nonwoody stems) that is native to arid and semiarid areas from the Mediterranean Basin to Siberia which was introduced to North America in the 1960s [2,4,5]. It has demonstrated potential as forage for multiple classes of livestock and wildlife [2,3,5], as well as for soil stabilization and reclamation on western rangelands $[6,7]$ due to drought tolerance [8], being more salt tolerant than alfalfa (Medicago sativa L.) and tall wheatgrass (Thinypyrum ponticum L.) [9], and being competitive against many annual weeds [10]. B. prostrata is different from its weedy annual relative, Kochia scoparia, because it is not invasive in perennial plant communities, spreading primarily by seed [3], and is not known to contain any compounds toxic to livestock $[2,5]$. 
Waldron et al. [2,3] reported biomass production of 1348 to $2471 \mathrm{~kg} \mathrm{ha}^{-1}$ in rainfed conditions of 100 to $200 \mathrm{~mm}$, but they also stated that some studies had measured yields of up to $6000 \mathrm{~kg} \mathrm{ha}^{-1}$. Bailey et al. [7] reported that the nutritive value of B. prostrata ranged from $8 \%$ to $12 \%$ crude protein and Harrison et al. [11] reported crude protein concentrations of $9 \%$ and 14\% in March and August, respectively, all of which were consistent to or slightly higher than that measured by Waldron et al. [3].

Fugal et al. [12] reported the nutritive value of winter-quiescent $B$. prostrata herbaceous branches to be $14.6 \%$ crude protein, $33 \%$ acid detergent fiber (ADF), and 55\% neutral detergent fiber (NDF), whereas Waldron et al. [3] measured an average of $36 \% \mathrm{ADF}, 50 \% \mathrm{NDF}$, and $63 \%$ in vitro true digestibility for virescens and grisea B. prostrata genotypes. These values are consistent to mid- to full bloom alfalfa [13], and consumption by grazing cattle (Bos Taurus) was similar between alfalfa and B. prostrata [5]. No supplementation was needed to maintain or increase body condition during late fall and winter [2]. Waldron et al. [5] reported that, unlike alfalfa, B. prostrata was not subject to grasshopper herbivory which allowed it to maintain crude protein levels, whereas alfalfa did not.

Bassia prostrata is well adapted over a broad range of latitudes $[6,7,12]$ and performs well in alkaline soils $[8,11]$ with successful establishment over a broad range of textures [6], although performance is better in light textured soils [4]. Additionally, salt tolerance is greater than alfalfa $[9,11]$, which, possibly, allows the use of lower quality irrigation water. Optimum precipitation is 200 to $430 \mathrm{~mm}$, but B. prostrata is drought hardy [8] and capable of growing under precipitation ranging from 125 to $700 \mathrm{~mm}$ [11]. Survival was nil in the Sonoran and southern Mojave Deserts of the USA, but satisfactory in the cold desert [14], as well as the semiarid regions of the Great Basin and similar environments. Many of the studies were conducted in regions having moist winter and dry summer seasons $[6,7,15]$ or the studies evaluated transplanted seedlings $[4,5,15]$ rather than direct seeding. No information was found in the literature evaluating B. prostrata under irrigation and only a study by Fugal et al. [12] was conducted in a region having dry winter and moist summer seasons, but they used transplanting rather than direct seeding. This study is a preliminary evaluation of the adaptation of selected B. prostrata genotypes to the irrigated continental dry winter and moist summer precipitation pattern of the Southern High Plains of the USA and similar environments established by direct seeding.

\section{Materials and Methods}

Four B. prostrata genotypes, i.e., subspecies virescens "Immigrant" (late maturing and high winter forage value) and "Pustinny-select" (early maturing experimental) and subsp. grisea "Snowstorm" (late maturing and tall enhanced winter forage value) and, "KZ-6X" (early maturing and salt tolerant experimental), from the authors' sources, were direct seeded on 19 March or 22 May 2014, at New Mexico State University's Agricultural Science Center at Tucumcari $\left(35.20^{\circ} \mathrm{N}, 103.69^{\circ} \mathrm{W}\right.$, elev. 1247 masl). The test area was Canez fine sandy loam (fine-loamy, mixed, superactive, thermic Ustic Haplargids) having $34 \mathrm{~kg}$ residual $\mathrm{N} \mathrm{ha}^{-1}$, and no fertilizers were applied at any time during the study. The test was designed as a split-split (planting date, winter (March) or spring (May)) (genotype) plot treatment arrangement with three randomized complete blocks. The test area had a winter cereal rye cover crop which was sown at $224 \mathrm{~kg}$ seed ha ${ }^{-1}$, with approximatley $15 \mathrm{~cm}$ of growth that had been terminated with $2.5 \%$ glyphosate. Plots were $2.75 \times 6.10 \mathrm{~m}$ of which the center $2.44 \times 6.10 \mathrm{~m}$ was disturbed with a rototiller, set to till the surface $5 \mathrm{~cm}$ immediately prior to planting $[6,7,14]$. After tilling, plots were rolled to firm the seedbed. The seeding rate was 441 pure live seed (PLS) $\mathrm{m}^{-2}$, which represented $2.8 \mathrm{~kg}$ PLS ha ${ }^{-1}$ for all entries except Snowstorm for which it represented $3.6 \mathrm{~kg}$ PLS ha ${ }^{-1}$ [3]. Seed was mixed with corn grit at a 1:2 w/w ratio to increase volume, and sowing was done with an EarthWay EV-N-SPRED hand broadcast spreader (EarthWay Products, Bristol, IN USA) set at 2.5. The spreader operator's gait was calibrated to apply most of the seed in two passes and the spreader was held approximately $1 \mathrm{~m}$ above ground level to cover approximately $2.44 \mathrm{~m}$ width. Seed of Snowstorm was considerably fluffier than the other entries and 3 to 4 passes were needed to distribute the seed mixture for that genotype. Seed mixture remnants after broadcasting were nearly negligible and were cast over the plot to empty the seeder. After seeding, an inverted leaf 
rake was dragged over each plot to promote seed-to-soil contact [14]. Following the winter seeding, sprinkler irrigations with Class 1B treated municipal wastewater $(167 \pm 15 \mathrm{ppm} \mathrm{Na}, 99 \pm 7 \mathrm{ppm} \mathrm{Cl}$, $1.29 \pm 0.25 \mathrm{mmhos} \mathrm{cm}^{-1}$ electrical conductivity, $n=6$ from 2014 to 2016) were occasionally applied (to maintain moist soil conditions.

Because 2014 was considered the establishment year, no herbicides were applied, and the test site was rotary mowed leaving a $15 \mathrm{~cm}$ stubble as needed to control competition by weeds without clipping any $B$. prostrata plants. Irrigations with treated municipal wastewater were applied occasionally throughout 2014 and during the winter of 2014 to 2015 to promote establishment (Table 1). After that, irrigation was only applied when canal water was available, either during the season or from stored water shortly after the season's end to prevent obvious moisture stress (Table 1). The presence of B. prostrata plants was verified in September 2014, although populations were sparse, and no quantitative observations were made.

On 5 May 2015, 4.79 $\mathrm{L} \mathrm{ha}^{-1}$ Prowl $\mathrm{H}_{2} \mathrm{O}$ (pendimethalin: N-(1-ethylpropyl)-3,4-dimethyl-2,6dinitrobenzenamine) were applied for pre-emergent weed control. High precipitation following that application limited residual control. Consequently, top growth, most of which was weeds, was removed on September 8 leaving a $15 \mathrm{~cm}$ stubble without clipping any B. prostrata plants. The test site was also mowed on 25 February 2016, and the clippings were left in situ to encourage stand thickening or expansion through seed drop. Borders were mowed again on 14 July 2016, to delineate subplots prior to being rated for percent canopy cover. The entire plot was rated for canopy cover. Stand thickening through seed production and mowing was encouraged again in the late fall and winters of 2016 and 2017 when maximum seed production was expected [16]. On 24 January 2017, the study area was rotary mowed to promote seed-to-soil contact and stand thickening. System failures at the city wastewater plant prevented irrigation from early October 2017 until late May 2018 and during the second half of August 2018.

Similarly, in 2016, entire subplot canopy cover was rated again on 2 August 2018, then, plots were delineated by mowing. Predominant weeds also were identified in each plot. On 5 September 2018, a $0.5 \mathrm{~m}^{2}$ area within a larger area having a fairly dense stand (estimated at $\geq 50 \%$ canopy cover) in each plot was measured for average canopy height and sampled for biomass to $<1 \mathrm{~cm}$ above ground level $[2,3]$. The number of plants were counted as they were hand clipped. Harvested biomass was dried for $96 \mathrm{~h}$ at $65^{\circ} \mathrm{C}$ and weighed to determine biomass in $\mathrm{kg} \mathrm{ha}^{-1}$. In addition, the number of plants within the quadrat was extrapolated to estimate potential plant population $\mathrm{ha}^{-1}$ if the entire plot had a uniform stand.

\section{Statistical Analyses}

Percent canopy cover data collected in 2016 and 2018 from the three replicates were analyzed using the MIXED procedure of SAS [17] to determine if differences existed between years (2016 and 2018), planting dates (March and May), and among B. prostrata genotypes and for all possible interactions. Percent canopy cover, potential plant population extrapolated from the $0.5 \mathrm{~m}^{2}$ areas, and biomass data within the three replicates, in 2018, were also analyzed using the MIXED procedure of SAS [17] to determine if differences existed between planting dates and among B. prostrata genotypes and for the interaction. For each analysis, replicates were considered random. When differences among B. prostrata genotypes or within any interaction were significant $(p \leq 0.05)$ or a trend $(0.05<p<0.10$ [18]) was evident, lsmeans were separated at $p \leq 0.05$ by least significant difference using the PDMIX800 SAS macro (Arnold M. Saxton, University of Tennessee, Knoxville, TN, USA, 2000). 
Table 1. Temperature and precipitation from 2014 to 2018 at Tucumcari, NM, and the long-term means (1905 to 2017) and irrigation amounts applied to Bassia prostrata using treated municipal wastewater.

\begin{tabular}{|c|c|c|c|c|c|c|c|c|c|c|c|c|c|c|c|c|c|}
\hline \multirow[b]{2}{*}{ Month } & \multicolumn{6}{|c|}{ Mean Temperature, ${ }^{\circ} \mathrm{C}$} & \multicolumn{6}{|c|}{ Total Precipitation, $\mathrm{mm}$} & \multicolumn{5}{|c|}{ Total Irrigation, $\mathrm{mm}$} \\
\hline & 2014 & 2015 & 2016 & 2017 & 2018 & Mean & 2014 & 2015 & 2016 & 2017 & 2018 & Mean & 2014 & 2015 & 2016 & 2017 & 2018 \\
\hline January & 3.9 & 2.2 & 3.3 & 3.9 & 3.3 & 3.5 & 0 & 37 & 0 & 26 & 0 & 10 & 0 & 0 & 0 & 0 & 0 \\
\hline February & 5.6 & 5.6 & 8.3 & 10.0 & 6.1 & 5.6 & 1 & 23 & 24 & 4 & 1 & 13 & 0 & 12 & 0 & 0 & 0 \\
\hline March & 9.4 & 10.0 & 11.7 & 6.7 & 11.1 & 9.6 & 6 & 10 & 2 & 55 & 4 & 1 & 77 & 50 & 0 & 0 & 0 \\
\hline April & 14.4 & 14.4 & 13.9 & 14.4 & 13.3 & 14.1 & 5 & 49 & 17 & 69 & 13 & 30 & 61 & 69 & 0 & 51 & 0 \\
\hline May & 18.9 & 16.7 & 18.9 & 17.8 & 22.2 & 19.1 & 61 & 102 & 33 & 46 & 46 & 51 & 139 & 0 & 51 & 51 & 25 \\
\hline June & 24.4 & 24.4 & 25.6 & 25.6 & 27.2 & 24.3 & 102 & 53 & 83 & 25 & 14 & 51 & 82 & 51 & 32 & 114 & 86 \\
\hline July & 26.1 & 26.7 & 28.9 & 27.8 & 27.2 & 26.2 & 65 & 192 & 28 & 40 & 29 & 71 & 100 & 13 & 120 & 114 & 51 \\
\hline August & 26.1 & 25.6 & 25.0 & 23.9 & 25.6 & 25.2 & 21 & 52 & 59 & 165 & 85 & 72 & 132 & 51 & 76 & 0 & 38 \\
\hline September & 21.1 & 24.4 & 22.8 & 21.1 & 22.2 & 21.4 & 69 & 33 & 10 & 67 & 20 & 42 & 51 & 82 & 114 & 82 & 151 \\
\hline October & 17.2 & 16.1 & 18.9 & 15.6 & 12.3 & 15.3 & 5 & 21 & 35 & 92 & 4 & 34 & 25 & 25 & 127 & 0 & 0 \\
\hline November & 7.2 & 8.9 & 11.0 & 11.9 & 11.0 & 8.6 & 9 & 31 & 2 & 0 & 1 & 17 & 25 & 0 & 0 & 0 & 0 \\
\hline December & 4.4 & 9.4 & 3.9 & 4.8 & 10.5 & 3.9 & 10 & 72 & 9 & 0 & 1 & 16 & 0 & 0 & 0 & 0 & 0 \\
\hline Mean/total & 14.9 & 15.4 & 16.0 & 15.3 & 16.0 & 14.7 & 354 & 674 & 304 & 590 & 218 & 407 & 693 & 353 & 520 & 412 & 352 \\
\hline
\end{tabular}




\section{Results and Discussion}

\subsection{Establishment}

Temperatures during the study period were slightly above average, especially during the summer months (Table 1). As is typical of the Southern High Plains and other semiarid regions with a continental precipitation pattern, precipitation was sporadic during the test period with vast differences among years in the amount and distribution. After the 2015 growing season, irrigations were only applied when canal water was available (generally mid-April through October, Table 1) because area producers generally do not have access to the wastewater or significant ground water for year-round irrigation. Bailey et al. [7] reported that, after being planted in December, B. prostrata could not survive in areas receiving 58 and $43 \mathrm{~mm}$ of precipitation from October through April during the first and second years, respectively, while it could survive having received $>75 \mathrm{~mm}$ during that period, even when there was a typical summer drought (May through October). Precipitation after planting, in this study, was more than sufficient to promote germination and growth for the May planting (Table 1); however, irrigation also was provided for the irrigated and range seedings in March. Nonetheless, both range seedings failed to establish. Hafercamp et al. [6] and Creech et al. [19] reported that late fall and winter seedings were more successful for establishment than early and late spring seedings in an area described as receiving 20 to $30 \mathrm{~cm}$ of precipitation annually, of which $60 \%$ fell between October and March, with frequent summer droughts. Aryal and Islam [10] to the north of the location of the present study and northeast of the studies by Hafercamp et al. [6] and Creech et al. [19] reported greater stand densities for April seedings than March seedings and seeding failure of May seedings. The location of Aryal and Islam [10] experiences dry winters and moist late springs and early summers consistent with the location of the present study, although, their study was not irrigated. Hafercamp et al. [6] observed deterioration that reduced germination which occurred during the winter when conditions were not satisfactory for germination. Haferkamp et al. [6] and Creech et al. [19] both suggested that sustained soil moisture was a critical factor in B. prostrata germination. For our study, seed was kept in cold storage until planting and irrigation was used to encourage germination [14,19]. Haferkamp et al. [6] stated that spring temperatures were more optimum for germination and suggested that if the period of moist soil could be extended into spring, potential establishment could be improved [14]. Fugal et al. [12] transplanted seedlings of $B$. prostrata and five other subshrubs at the beginning of the rainy season in December (their summer period) at a high elevation in tropical Bolivia and found that B. prostrata was only one of two species that survived, the other being Atriplex canescens. Bassia prostrata's drought hardiness is due in part to its deep roots and, apparently, it is not as drought hardy during the establishment or transplanting phase [2,11].

After establishment, plants of all genotypes remained short and prostrate for the first two growing seasons with $<15 \mathrm{~mm}$ height, consistent with the report of Bailey et al. [7]. Predominant weeds in 2016 and 2018 included sand dropseed, marestail (Conyza canadensis (L.) Cronquist), carelessweed (Amaranthus palmeri S. Watson), silverleaf nightshade (Solanum elaeagnifolium Cav.), annual kochia (Kochia scoparia), curlycup gumweed (Grindelia squarrosa (Pursh) Dunal), toothed spurge (Euphorbia dentata Michx.), and honey mesquite (Prosopis glandulosa Torr.). These all became established in areas not occupied by B. prostrata plants. Several researchers have reported that B. prostrata became established despite a dense stand of weeds $[8,10,20]$. Harrison et al. [11] stated that B. prostrata did not typically grow as a monoculture in its area of origin. Whereas, Davies and Johnson [15] stated that sporadic establishment by B. prostrata was a concern when reclaiming land from exotic annual grasses and suggested that perennial bunchgrasses that are easily established should be sown with the B. prostrata to achieve more successful reclamation. Waldron et al. [3] also suggested that B. prostrata be planted with adapted grasses for greater production and nutritive value for grazing. Peel et al. [21,22] reported that B. prostrata mixed well with Siberian wheatgrass (Agropyron fragile L.) and Altai wildrye (Leymus angustus L.), the latter of which is well adapted to the environment of this study [23]. Sand dropseed, a warm-season perennial bunchgrass that is adapted to the area of this study and easily 
established [24], could also be compatible with forage kochia while providing competition against the weedy species observed in the plots. Nonetheless, Aryal and Islam [10] reported a reduction in $B$. prostrata plant density when it was sown with various perennial grasses.

\subsection{Canopy Cover Measurement}

Neither the main effects of year nor planting date were significant nor were there any significant interactions with year for percentage canopy cover rated in 2016 and $2018(p>0.60,0.41,0.67,0.58$, and 0.94 for the year, planting date, year $\times$ planting date, year $\times$ genotype, and year $\times$ planting date $\times$ genotype effects, respectively). The lack of any year effect suggested that efforts made to thicken the stand, by producing seed and mowing each year, were not effective in this environment and management. Other reports suggest that, although Immigrant was self-sustaining with new seedlings [3,4,11] and dense stands of $B$. prostrata did not allow re-invasion by weedy annual species [15], it also did not spread outside of the initial seeding unless the area of invasion was reduced to bare ground [4,11]. Additionally, Immigrant did not compete as well in higher precipitation areas in a closed plant community [4,11]. Precipitation, in our study, was generally $>350 \mathrm{~mm}$ annually [11] and was supplemented by irrigation (Table 1). In some cases, there were areas within the plots of the virescens genotypes that had uniform cover, but also areas without any plants. The grisea genotypes generally had few plants that were distributed throughout the stand, although KZ-6X did have plot areas sufficient for biomass sampling. Lack of stand expansion from seed drop also could be due to the dry winters, which are common to semiarid continental precipitation regions (Table 1), with no supplemental irrigation, as opposed to the moist winters where B. prostrata has been evaluated without irrigation elsewhere $[4,7,11]$. The application of Prowl $\mathrm{H}_{2} \mathrm{O}$ in May 2015 did not likely have any effect on seedling recruitment despite the listing of the weedy annual, K. scoparia (Kochia) as a controlled weed on the Prowl $\mathrm{H}_{2} \mathrm{O}$ label (http://www.cdms.net/ldat/ld6CT004.pdf) and the maximum application rate was used. The application was made after the likelihood of late winter or spring germination of seeds produced the previous year and heavy rain followed the application, limiting any residual effect as indicated by the presence of other labeled weeds germinating shortly after the application. Additionally, the initial set of canopy cover ratings was taken more than 12 months after the application, and the second set was taken two years later, but there was no change in canopy cover between 2016 and 2018. Since no stand expansion took place from 2016 to 2018, it was assumed that most plants had established from the original seeding, which used seed that had been kept frozen between arrival from the USDA-ARS Forage and Range Lab and planting time as per the recommendation of Kitchen and Monson [14].

Differences existed among B. prostrata genotypes with the virescens having greater $(p<0.0001)$ canopy cover than the grisea genotypes $(29,27,<1$ and $14 \%$, canopy cover for virescens entries Immigrant and Pustinny-select and grisea entries Snowstorm and KZ-6X, respectively, SEM =6). This is contrary to the findings of Bailey et al. [7], who reported greater seedling establishment rankings for grisea cultivars than for virescens. Environmental differences, including a continental climate, in this study with $80 \%$ of precipitation falling between April and October as compared with a climate with $100 \%$ of the precipitation falling between October and April for the study by Bailey et al. [7], could have been a factor in the difference in establishment. Soil temperatures for the March planting were approximately $10{ }^{\circ} \mathrm{C}$ and for the May planting they were $18{ }^{\circ} \mathrm{C}$, which were within the range for germination and seedling survival [11]. There also was a planting date $\times$ genotype interaction for canopy cover because, while Immigrant had greater canopy cover when planted in March, the improved virescens genotype, Pustinny-select, had greater canopy cover when planted in May (Table 2). 
Table 2. Canopy cover percentages of Bassia prostrata (L) A.J. Scott by genotype and planting date (in 2014). Data are the means of ratings taken 2 and 4 years after planting (no year effect or interaction with year, $p<0.6093$ and $p<0.9498$, respectively) and 3 replicates.

\begin{tabular}{cccccc}
\hline & & \multicolumn{4}{c}{ Planting Date } \\
\hline Subspecies & Genotype & \multicolumn{2}{c}{ March } & \multicolumn{3}{c}{ May } \\
\hline & & \multicolumn{4}{c}{$\%$ Cover } \\
\hline grisea + & Snowstorm & 1 & C $~$ & 0 & $\mathrm{C}$ \\
grisea & KZ-6X & 8 & BC & 14 & BC \\
virescens & Immigrant & 38 & A & 20 & B \\
virescens & Pustinny-select & 14 & BC & 40 & A \\
\hline
\end{tabular}

† Subspecies names are provided for reference only; $\ddagger$ Genotype lsmeans within the interaction $(p<0.0083)$ followed by common letters are not significantly different at $p<0.05, \mathrm{SEM}=8$.

In comparison, Waldron et al. [3] found that, on average, establishment by Snowstorm, Pustinny-select, Immigrant, and KZ-6X were not different in cultivated ground across a broad range of locations, whereas, Creech et al. [19] concluded that subsp. grisea (not Snowstorm) had greater field germination than subsp. virescens (Immigrant). Smith et al. [8], within the same range of latitudes and longitudes using no-tillage, reported no differences in transplant survival among B. prostrata ploidy levels for transplants; however, when no-till seeded, only the diploid, subsp. virescens (i.e., Immigrant and Pustinny-select in the present study and Immigrant in Smith et al. [8]) had greater plant density than the control (no seeding), while the subsp. grisea tetraploid (i.e., Snowstorm) and the hexaploid entries (i.e., KZ-6X) were significantly lower than Immigrant. These results for Immigrant and Snowstorm are consistent to the present study (Table 3). Creech et al. [19] speculated that greater germination of grisea was due to larger seed size; however, Waldron et al. [3] rejected their own hypothesis that greater seed weight of grisea Snowstorm would confer greater seedling vigor and establishment.

Table 3. Planting date (PD) and genotype effects on potential plant population, canopy height, and biomass of Bassia prostrata (L) A.J. Scott genotypes sown in 2014 at Tucumcari, NM, USA, and estimated from a $0.5 \mathrm{~m}^{2}$ area within an area of dense stand ( $\geq 50 \%$ canopy cover) in 2018 . Data are the lsmeans of three replicates.

\begin{tabular}{|c|c|c|c|c|c|c|}
\hline Treatment & \multicolumn{2}{|c|}{ Potential Plant Population } & \multicolumn{2}{|c|}{ Canopy Height } & \multicolumn{2}{|c|}{ Biomass } \\
\hline PD & \multicolumn{2}{|c|}{ Plants $\mathrm{m}^{-2}$} & \multicolumn{2}{|c|}{$\mathrm{cm}$} & \multicolumn{2}{|c|}{$\mathrm{kg} \mathrm{ha}^{-1}$} \\
\hline March & 10.4 & & 64.3 & & 8909 & \\
\hline May & 9.5 & & 71.2 & & 12,357 & \\
\hline SEM & 1.9 & & 6.2 & & 2454 & \\
\hline \multicolumn{7}{|l|}{ Genotype } \\
\hline KZ-6X & 8.6 & $A+$ & 55.1 & $\mathrm{AB}$ & 8106 & $\mathrm{AB}$ \\
\hline Immigrant & 15.1 & B & 72.6 & $\mathrm{~B}$ & 11,060 & $\mathrm{~B}$ \\
\hline Pustinny-select & 6.1 & B & 75.5 & A & 12,732 & A \\
\hline SEM & 1.8 & & 5.9 & & 2410 & \\
\hline \multicolumn{7}{|c|}{$p$-values } \\
\hline PD & \multicolumn{2}{|c|}{0.5380} & \multicolumn{2}{|c|}{0.3065} & \multicolumn{2}{|c|}{0.0953} \\
\hline Genotype & \multicolumn{2}{|c|}{0.0302} & \multicolumn{2}{|c|}{0.0509} & \multicolumn{2}{|c|}{0.1021} \\
\hline PD $\times$ Genotype & \multicolumn{2}{|c|}{0.4657} & \multicolumn{2}{|c|}{0.4631} & \multicolumn{2}{|c|}{0.1554} \\
\hline
\end{tabular}

+ Genotype lsmeans within a column followed by common letters are not significantly different at $p<0.05$, based on least significant difference analysis.

\subsection{Plant Population, Canopy Height, and Biomass in 2018}

For data collected, in 2018, from within the $0.5 \mathrm{~m}^{2}$ area, potential plant population of grisea KZ-6X was approximately double that of the two virescens genotypes (Table 3, [7]). All this 
being stated, potential populations in this study (Table 3) were considerably greater than seedling estimates by Waldron et al. [3], who reported 1.4, 1.2, and 1.2 seedlings $\mathrm{m}^{-2}$, for KZ-6X, Immigrant, and Pustinny-select, but intermediate to Aryal and Islam [10], who reported densities of 4.3 and 25.8 plants $\mathrm{m}^{-2}$ for year-old stands sown in March and April, respectively. Smith et al. [8] also reported lower plant populations at 2.3 and 0.8 plants $\mathrm{m}^{-2}$ for no-till and conventional tillage plantings, respectively.

Interestingly, the report of greater populations with no-tillage [8] is contrary to the findings of other studies stating that establishment is best in disturbed sites $[6,7,14]$ and broadcast planting is more effective than drill seeding [3]. Aryal and Islam [10] reported greater plant densities for a drilled April planting on tilled ground as compared with a broadcast seeding over snow in March and a failed May seeding using the drill on tilled ground. They [10] attributed lower plant densities for the March seeding to fluctuating temperature and moisture conditions soon after seeding rather than to the seeding technique. While Aryal and Islam [10] reported a difference in stand counts for March and April plantings, they found no change in B. prostrata plant density from the seeding year to the year after seeding for either planting date.

Canopy heights of four-year-old plants in this study were consistent to or taller than those of other studies ([4], for plants of similar age; [5,7]). There was a trend $(0.05<p<0.10$ [18]) towards a difference among $B$. prostrata genotypes for canopy height, such that, both improved genotypes (grisea KZ-6X and virescens Pustinny-select) were taller than virescens Immigrant (Table 3). It was not surprising for the grisea genotype to be taller than the virescens genotypes because grisea is naturally taller than virescens [2,3], and for the improved virescens genotype to be taller than Immigrant because it was developed for taller stature [7]. Aryal and Islam [10] reported a slight increase in plant height from the seeding year to the year after seeding and Bailey et al. [7] measured a height increase of approximately three-fold from that of the first to second year after planting which is consistent to the increase from the prostrate plants $<15 \mathrm{~cm}$ tall, five months after seeding and those measured 4.5 years after seeding in the present study (Table 3). Waldron et al. [3] reported a $23 \%$ height difference between Immigrant and KZ-6X and a 43\% height difference between Immigrant and Pustinny-select. Differences, in the present study, were 23 and 37\%, respectively (calculated from Table 3). Bailey et al. [7] observed no difference between genotypes in plant height but did measure a difference in height between locations attributing that to a difference in precipitation during the study period. Irrigation used, in the present study, could have allowed the genotypes to express height differences that could not be expressed in unirrigated, low precipitation $\left(<110 \mathrm{~mm} \mathrm{yr}^{-1}\right.$ ) occurring between October and April, which was the case for the study by Bailey et al. [7].

In this study, the biomass estimates to ground level of the B. prostrata (Table 3) were similar to or slightly greater than those for alfalfa grown in the same field and irrigated year round to supplement precipitation with a fully functional treated municipal wastewater irrigation system [25]. Waldron et al. [5] reported B. prostrata biomass approximately two-fold that of alfalfa under rainfed conditions in a moist winter and dry summer environment and that the B. prostrata was consumed equally well to the alfalfa by mature cows.

While each of the $0.5 \mathrm{~m}^{2}$ areas sampled had $\geq 50 \%$ canopy cover in the quadrat, there also was a trend $(0.05<p<0.10$ [18]) toward a difference between planting dates for biomass with plants from the May planting having greater biomass than those of the March planting (Table 3), although planting had taken place four years earlier. Additionally, there was nearly a trend $(0.05<p<0.10$ [18]) toward a difference among genotypes for biomass production for stands having $\geq 50 \%$ canopy cover, such that the improved virescens Pustinny-select genotype had greater biomass than virescens Immigrant, with grisea KZ-6X being intermediate (Table 3). The biomass rankings and significant differences among KZ-6X, Immigrant, and Pustinny-select, in this study, are similar to those reported by Waldron et al. [3], but the biomass yields were considerably greater in this study. Peel et al. [21] measured B. prostrata biomass of $5.0 \mathrm{Mg} \mathrm{ha}^{-1}$ in each of the two years after transplanting when mixed with Siberian wheatgrass, although at a much lower plant population. Likewise, Waldron et al. [3] reported biomass of just under 
2.24 $\mathrm{Mg} \mathrm{ha}^{-1}$ averaged over 10 years for sites at five locations when measured from the same stand age and similar plant populations as Peel et al. [21]. In addition to plant population and harvest technique, differences between this and other studies are possibly due to the greater stand age (4.5 years vs. 1 to 2 years), a longer growing season, and the application of irrigation water. Fugal et al. [12] reported that DM biomass of $B$. prostrata estimated during the winter quiescent period increased nearly three-fold from the first to second year after transplanting. This would be consistent to the previously mentioned increase in canopy height of plants in our study from being prostrate in the first year to having an upright stature in the fourth year (Table 3).

Biomass in $\mathrm{g} \mathrm{plant}^{-1}\left(206 \pm 199 \mathrm{~g} \mathrm{plant}^{-1}\right)$ was within the range of that measured across sites by McArthur et al. [4] in a single year, two years after transplanting, and Waldron et al. [5] two and three years after transplanting. These studies by McArthur et al. [4] and Waldron et al. [5] were at latitudes similar to each other with biomass estimations made in August or September, near or after the cessation of growth for the season. The B. prostrata, in this study would likely have been still actively growing, being at a lower latitude, although minimal regrowth occurred after harvest. Additionally, as mentioned, this study was irrigated. Waldron et al. [5] reported that despite a significant year $\times$ entry interaction, the greater and lesser yielding entries were generally consistent across years, although precipitation differences were vast and had an effect on the average $g$ plant $^{-1}$. It is not known what effect the irrigation system shutdowns had on B. prostrata biomass production in 2018; however, even without the supplemental water and despite lower than average precipitation during the period (Table 1), the B. prostrata produced considerable biomass (Table 3).

\section{Conclusions}

In this preliminary study, B. prostrata did not establish satisfactorily when direct seeded in March and May without irrigation at this location in the Southern High Plains of the USA, which has a dry winter and moist summer precipitation pattern. The virescens genotypes established greater canopy cover from initial seedings under irrigation than the grisea genotypes. Grisea Snowstorm did not establish. Immigrant had greatest canopy cover of the March seeding and Pustinny-select had greatest canopy cover of the May seeding.

This study was limited in scope due to a single seeding year and the environmental influences, particularly, precipitation, during that year may have been a factor in establishment. On the basis of the results of this study, Pustinny-select seeded in mid-spring, as opposed to late winter or early spring, with conventional tillage under irrigation would be the basis for any future research, much of which is needed before any recommendations can be made.

Author Contributions: Conceptualization, L.L. and B.W.; methodology, L.L. and B.W.; validation, L.L. and B.W.; formal analysis, L.L. and B.W.; investigation, L.L. and B.W.; resources, L.L. and B.W.; data curation, L.L. and B.W.; writing-original draft preparation, L.L. and B.W.; writing—review and editing, L.L. and B.W.; supervision, L.L. and B.W.; project administration, L.L. and B.W. All authors have read and agreed to the published version of the manuscript.

Funding: This research received no external funding.

Acknowledgments: The authors gratefully acknowledge the technical and field assistance of Jason Box, Ashley Cunningham, Jared Jennings, Shane Jennings, Anthony Williams; secretarial assistance of Patty Cooksey; and the staffs with the NMSU Library Document Delivery Service; the NMSU College of Agricultural, Consumer and Environmental Sciences Information Technology; and other University support services. Salaries and research support were provided by state and funds appropriated to the New Mexico Agricultural Experiment Station, including the USDA National Institute of Food and Agriculture Hatch projects 221381, 1004803, and 1021538.

Conflicts of Interest: The authors declare no conflict of interest.

\section{References}

1. Ibrahim, M.; Ayub, M.; Maqbool, M.M.; Nadeem, S.M.; Ul Haq, T.; Hussain, S.; Ali, A.; Lauriault, L.M. Forage yield components of irrigated maize-legume mixtures at varied seed ratios. Field Crops Res. 2014, 169, 140-144. [CrossRef] 
2. Waldron, B.L.; Eun, J.-S.; ZoBell, D.R.; Olson, K.C. Forage Kochia (Kochia prostrata) for fall and winter grazing. Small Rumin. Res. 2010, 91, 47-55. [CrossRef]

3. Waldron, B.L.; Larson, S.R.; Peel, M.D.; Jensen, K.B.; Mukimov, T.C.; Rabbimov, A.; ZoBell, D.R.; Wang, R.C.; Smith, R.C.; Harrison, R.D.; et al. 'Snowstorm', a new forage kochia cultivar with improved stature, productivity, and nutritional content for enhanced fall and winter grazing. J. Plant Registr. 2013, 7, 140-150. [CrossRef]

4. McArthur, E.D.; Sanderson, S.C.; Davis, J.N. Adaptation of forage kochia accessions across an environmental gradient in Rush Valley, Utah. Arid Soil Res. Rehab. 1996, 10, 125-138. [CrossRef]

5. Waldron, B.L.; Davenport, B.W.; Malechek, J.C.; Jensen, K.B. Relative cattle preference of 24 forage kochia (Kochia prostrata) entries and its relation to forage nutritive value and morphological characteristics. Crop Sci. 2010, 50, 2112-2123. [CrossRef]

6. Hafercamp, M.R.; Ganskopp, D.C.; Marietta, K.L.; Knapp, B.W. Environmental influences on germination of utricles and seedling establishment of 'immigrant' forage Kochia. J. Range Manag. 1990, 43, 518-522. [CrossRef]

7. Bailey, D.W.; al Tabini, R.; Waldron, B.L.; Libbin, J.D.; Al-Khalidi, K.; Alqadi, A.; al Oun, M.; Jensen, K.B. Potential of Kochia prostrata and perennial grasses for rangeland restoration in Jordan. Rangel. Ecol. Manag. 2010, 63, 707-711. [CrossRef]

8. Smith, R.C.; Waldron, B.L.; Creech, J.E.; Zobell, R.A.; ZoBell, D.R. Forage kochia and Russian wildrye potential for rehabilitating Gardner's saltbush ecosystems degraded by halogeton. Rangel. Ecol. Manag. 2016, 69, 390-398. [CrossRef]

9. Sagers, J.K.; Waldron, B.L.; Creech, J.E.; Mott, I.W.; Bugbee, B. Salinity tolerance of three competing rangeland plant species: Studies in hydroponic culture. Ecol. Evol. 2017, 7, 10916-10929. [CrossRef] [PubMed]

10. Aryal, P.; Islam, M.A. Establishment of forage Kochia in seeding mixtures with perennial grasses. Grassl. Sci. 2018, 65, 147-154. [CrossRef]

11. Harrison, R.D.; Chatterton, N.J.; Waldron, B.L.; Davenpoort, B.W.; Palazzo, A.J.; Horton, W.H.; Asay, K.H. Forage Kochia: Its Compatibility and Potential Aggressiveness on Intermountain Rangelands; Utah Agricultural Experiment Station: Salt Lake County, UT, USA, 2000.

12. Fugal, R.A.; Anderson, V.J.; Roundy, B. Exotic grass and shrub production evaluation and llama performance on the Bolivian Altiplano. Small Rumin. Res. 2010, 94, 150-160. [CrossRef]

13. Marsalis, M.A.; Hagevoort, G.R.; Lauriault, L.M. Hay Quality, Sampling, and Testing; Circ. 641; New Mexico State University Cooperative Extension Service: Las Cruces, NM, USA, 2009; Available online: http://aces.nmsu.edu/pubs/_circulars/CR-641.pdf (accessed on 11 October 2018).

14. Kitchen, S.G.; Monson, S.B. Forage kochia seed germination response to storage time and temperature. J. Range Manag. 2001, 54, 299-306. [CrossRef]

15. Davies, K.W.; Johnson, D.D. Established perennial vegetation provides high resistance to reinvasion by exotic annual grasses. Rangel. Ecol. Manag. 2017, 70, 748-754. [CrossRef]

16. Creech, C.F.; Waldron, B.L.; Ransom, C.V.; ZoBell, D.R.; Creech, J.E. Influence of harvest date on seed yield and quality in forage kochia. Front. Agric. Sci. Eng. 2018, 5, 71-79. [CrossRef]

17. SAS Institute. The SAS System for Windows, Release 9.3; SAS Institute: Cary, NC, USA, 2010.

18. Ramsey, F.L.; Schafer, D.W. The Statistical Sleuth: A Course in Methods of Data Analysis, 2nd ed.; Duxbury: Pacific Grove, CA, USA, 2002; p. 42.

19. Creech, C.F.; Waldron, B.L.; Ransom, C.V.; ZoBell, D.R.; Creech, J.E. Factors influencing the field germination of forage kochia. Crop Sci. 2013, 53, 2202-2208. [CrossRef]

20. Monaco, T.A.; Waldron, B.L.; Newhall, R.L.; Horton, W.H. Re-establishing perennial vegetation in cheatgrass monocultures. Rangelands 2003, 25, 26-29. [CrossRef]

21. Peel, M.D.; Jensen, K.B.; Waldron, B.L.; Robins, J.G. Forage yield of grass-alfalfa and grass-forage kochia mixtures on semiarid rangelands. Forage Grazingl. 2011, 9. [CrossRef]

22. Peel, M.D.; Waldron, B.L.; Jensen, K.B.; Robins, J.G. Alfalfa and forage kochia improve nutritive value of semiarid rangelands. Forage Grazingl. 2013, 11. [CrossRef]

23. Lauriault, L.M.; Kirksey, R.E.; VanLeeuwen, D.M. Performance of perennial cool-season forage grasses in diverse soil moisture environments, Southern High Plains, USA. Crop Sci. 2005, 45, 909-915. [CrossRef] 
24. Tilley, D.; St John, L.; Ogle, D. Plant Guide for Sand Dropseed (Sporobolus cryptandrus); USDA-Natural Resources Conservation Service, Idaho Plant Materials Center: Aberdeen, ID, USA, 2009; p. 4. Available online: https://plants.usda.gov/plantguide/pdf/pg_spcr.pdf (accessed on 11 October 2018).

25. Lauriault, L.M.; Ray, I.; Pierce, C.; Burney, O.; Flynn, R.P.; Marsalis, M.A.; O’Neill, M.K.; Cunningham, A.; Havlik, C.; West, M. The 2017 New Mexico Alfalfa Variety Test Report; New Mexico State University Cooperative Extension Service: Las Cruces, NM, USA, 2018. Available online: http://aces.nmsu.edu/pubs/variety_trials/ AVT17.pdf (accessed on 12 October 2018).

(C) 2020 by the authors. Licensee MDPI, Basel, Switzerland. This article is an open access article distributed under the terms and conditions of the Creative Commons Attribution (CC BY) license (http://creativecommons.org/licenses/by/4.0/). 